\title{
Optimization of an Off-Grid Hybrid System Using Lithium Ion Batteries
}

\author{
Paul Arévalo Cordero ${ }^{1}$, Juan Lata García ${ }^{2}$, Francisco Jurado ${ }^{1}$ \\ ${ }^{1}$ Department of Electrical Engineering of the University of Jaén, 23009 Jaén - \\ Spain*; E-mails: wpac0001@red.ujaen.es, fjurado@ujaen.es \\ ${ }^{2}$ Department of Electrical Engineering Salesite Polytechnic University GIPI, \\ 090101 Guayaquil-Ecuador; E-mail: jlatag@ups.edu.ec
}

\begin{abstract}
Distributed generation represents an optimal solution for energy problems in remote sites, where access to energy distribution companies is difficult. This article therefore presents the modeling and optimization of an electric power system based on hybrid renewable energy (photovoltaic/hydrokinetic/diesel), combined with a Lithium Ion battery storage system. The analysis is performed using two methods. The first is a computational model based on mathematical equations using the Simulink Design Optimization (SDO) tool in Matlab. The second is a simulation of the hybrid system using the HOMER Software. The results show that the highest annual energy contribution corresponds to the hydrokinetic generation system (78.87\%), the photovoltaic generation with a percentage of $19.59 \%$ and the penetration of the diesel generator is the lowest with $1.53 \%$. In addition, the Nelder-Mead algorithm (SDO) shows a lower number of diesel generator starts, increasing the capacity of the batteries.
\end{abstract}

Keywords: Hydrokinetic turbine; Solar panels; Renewable energy; Hybrid System

\section{Introduction}

Considering the population increase, the reduction of oil reserves and evident negative climate change produced by a hydrocarbon based economy, renewable energies should be further developed in the coming years. Therefore, further research in this field is necessary. Furthermore, the planet can have enough renewable resources to cover global electricity demand, the energy being the main source of development, especially in countries where not the entirety of the population has electricity [1]. However, in Ecuador, there are few rural electrification projects and even less in Amazonian populations such as Kichwa, Siona and Achuar, which require electrical energy for development in their daily activities. However, in Ecuador there are few rural electrification projects and even less in Amazonian populations. Therefore, it is necessary to carry out 
research projects on possible electrification taking advantage of the natural resources of rural areas [2].

Electricity service in Ecuador is $97.04 \%$. However, the lowest rate of electrification is present in the Amazon region [1]. The deficit of electricity in these regions is the result of limited reach of distribution companies, but the main reason is the remote area of these communities, since they are located hundreds of kilometers away from the main distribution centers. For this reason, the viability of generating electricity with renewable sources in the consumption zone is analyzed. The Agency for Regulation and Control of Electricity (ARCONEL) authorized the construction of photovoltaic energy projects in 2018, with a preferential rate of USD 0.40 per kilowatt hour $(\mathrm{kWh})$ of generation, since the country has a high rate of solar resource [1].

In Ecuador, one of the main sources of electricity generation is hydroelectric, since the country is located in the middle of the Andes Mountain Range, therefore it has high water resources.

According to the Ministry of Electricity and Alternative Energies, in 2023, the country will have more than $90 \%$ of hydroelectric generation. In the case of remote communities, a practical solution could be to generate electricity with hydrokinetic turbines located in the consumption sites. Unlike a hydroelectric plant, hydrokinetic turbines do not require the construction of dams for reservoirs, they simply require a continuous flow of water. There are recent studies of technical-economic feasibility for the use of this type of turbines in remote communities with favorable results [3] [4]. The "Nuevo Rocafuerte" community does not have $100 \%$ electricity coverage. Nowadays, electricity is produced by diesel genera-tors, even though it is located next to the Napo River, therefore it has a lot of water [5].

Considering the abundant water and solar resources in the area, two renewable sources could be combined in a hybrid electric power generation system (PV / HKT / DG / Li-ion). Lithium Ion batteries have a higher energy density than the acid lead, apart from having a life cycle greater than 10 years, have greater depth of discharge (SOC) [6]. In this way, the demand of the community could be efficiently supplied by hybrid systems [7]-[13]. The proposed hybrid system will be analyzed through the HOMER software [14], that allows to determine the optimal configuration of the system, and a simulation in Matlab Simulink Design Optimization (SDO), in order to ensure the best configuration and energy reliability of the community. The determination of the sizing of a hybrid system of renewable energies is increasingly notable. Different authors have investigated methods that guarantee the optimization of the system, adding multiobjective functions and studies of demand prediction, [15]. The hybrid system that is most researched is the combination of photovoltaic and wind energy. The reference [16], explains the sizing of the hybrid system composed of (PV-Wind) in a remote 
area of Tunisia obtaining the results of sizing optimization, and other isolated systems [17]-[26].

In the reference [14], performs an economic feasibility analysis by using a hybrid system to reduce environmental pollution, using different fuels to find the best configuration using Homer software, showing that a hybrid system can supply the demand without violating any restrictions.

In relation with the storage system, the most common ones are lead acid batteries and hydrogen tanks. The backup systems are typically DG and electrolysers (FC), in some cases supercapacitors [27], today more authors use lithium ion batteries as a storage system due to their high efficiency [6] [28].

In reference [4], determines the optimal sizing of a Hybrid System of Renewable Energies (PV / HKT / DG) in an island located on the Ecuadorian coast. The study demonstrates that the system can supply off-grid loads, which could be analyzed on a large scale, especially evaluating the stability of the system with high penetration of renewables, however it could be further optimized with the use of Lithium Ion batteries, taking into consideration the impact on the hybrid system using this storage technology.

Renewable systems have proven to be an effective alternative by reducing the consumption of fossil fuels. The reference [29], explains the gradual reduction of diesel consumption in a remote community of Indonesia using solar panels and batteries. Moreover, in [30] analyzes energy management and optimization of battery size for a micro-grid located on an island in Australia with novel results.

On the other hand, photovoltaic and hydroelectric solar energy has been developed in Ecuador during the last decade [31]. Today, there are many studies of hybrid renewable systems in remote communities encouraging the use and optimization of renewable resources. The study conducted by [4], explains that a hybrid system (PV/HKT/DG/Lead acid Battery) has the capacity to supply the demand of an off-grid community. It is noteworthy that the acid lead battery has a short life cycle. In the same way, [25] discusses replacing the diesel generation system with fuel cells, yet fuel cells are expensive. In addition, this work may be extended in the future to include hydrogen and different storage systems.

The difficulty in designing the sizing of renewable systems focuses on the randomness of resources for their sources, in conventional systems the information is insufficient to simulate and predict complex systems. In reference [32], the author shows the use of fuzzy cognitive maps, with the aim of representing dynamic systems by means of migration algorithms, as convenient means of adaptation. Through this method it has been possible to combine several variables to approach the optimal solution of a renewable system. Research based on improving the behavior of renewable energy sources proposes different methods, as in the case of [33], this paper proposes a convergent IFT algorithm for single-entry discrete time systems using fuzzy control logic, this type of control 
systems can process non-linearity is better than other control systems, although the error is non-zero, but this type of control could be useful to help the convergent algorithms that are part of renewable systems through an adequate analysis of stability and convergence. The improvement in the use of optimization algorithms are increasingly evident, in [34] has presented an ideal gas optimization algorithm (IGO), which is based on the first law of thermodynamics and kinetics, basically uses the grouping of gas molecules in each iteration to find non-uniform spaces finding suboptimal. This algorithm has a greater capacity and efficiency of analysis than some highly used algorithms, such as particle swarm (PSO) and genetic algorithm (GA). Similarly, different types of algorithms are discussed in [35]-[38], these studies present the different types of algorithms inspired by nature, focused mainly on diffuse control (Takagi-Sugeno, Swarm of Particles, Gravitational Search), hybrids (Swarm of Particles-Gravitational Search) and adaptive (Gravitational Search).

In the papers [9] [39], several optimization algorithms have been used, among them: basic equation, SDO (genetic algorithm, latyn hypercube) and Hoga and Homer software, in order to find optimal values in a hybrid system composed of PV/WT/FC systems, the results show that the best configuration found corresponds to the SDO method, performing a technical optimization through the application of genetic algorithm.

Similarly, in [12] the same hybrid system has been analyzed. However, the simulation was carried out only in Matlab software, through 3 dispatch strategies combining lead acid batteries and FC cells. The results have shown that, combining both storage systems, the results are more energy efficient. On the other hand, reference [40] has carried out an optimization analysis of a hybrid system composed of HKT/PV/lead acid batteries, using two methods: SDO and Homer software, the results have shown that the best result is found through SDO (Latin Hypercube algorithm), reducing the operation of the DG. In addition, this article has obtained similar results. The Matlab software through its SDO tool has obtained the best technical result using the Nelder-Mead algorithm, reducing the penetration of the diesel generator.

Several authors present problems of optimization with respect to hybrid systems composed of renewable energy, such as Homer software, which is highly accepted by the scientific community and has several libraries that facilitate the analysis of data. On the other hand, Matlab has many tools to improve the optimization of the parameters of a system and can be edited as necessary. Therefore, it is important to analyze a renewable hybrid system using both methods [9].

El software Matlab (SDO) puede proporcionar opciones de simulación en el dominio del tiempo y la frecuencia, utilizando la interfaz gráfica de usuario (GUI). In addition, it is possible to impose limits for the study of several signals. The design variables need to be declared in SDO as well as their limits, for example the SOC of a lithium ion battery, the charge limits of the battery must be 
maintained in SOCmin of $20 \%$ and SOCmax of $100 \%$. Then, the variables to be optimized must be defined, such as the size of the batteries, PV and HKT. In addition, it is possible to choose the optimization method in SDO, among them: gradient gescent, pattern search and simplex search. In several cases, it has been concluded that the pattern search method is able to find the appropriate parameters in the simulation. Within this method, optimization algorithms such as: Latin hypercube, genetic algorithm and Nelder Mead, should be chosen. Finally, the following parameters are defined for the optimization of the control process [9].

Parameter tolerance: the optimization process ends when successive parameters values change less than this number.

Constraint tolerance: this parameter represents the maximum relative amount by which the constraints can be violated and still allow a successful convergence.

Function tolerance: this parameter is used to end the optimization when successive function values are less than this value. This parameter is only useful when Simplex Search method is selected. Its value does not matter in our study.

Maximum iterations: define the maximum number of iteration allowed in the optimization process.

The general objective of this study is to optimize hybrid system using Lithium Ion batteries in order to analyze the resulting effects. The originality of this study is reflected in the type of storage system, which by the combination of two renewable sources must provide clean and reliable energy to the community under study. In addition, the battery replacement time should be reduced. Therefore, this study is organized as follows: mainly, the study area is analyzed, obtaining data such as solar radiation, river velocity and electric demand, then the mathematical modeling of the generation sources (PV/HKT/DG) and storage of Lithium Ion (Liion), to later perform the simulation using the Matlab tool (Simulink design optimization) and in the Homer software. Hence, by obtaining system sizing results that will be analyzed with the purpose of determining the optimal configuration.

\section{Case Study}

The case study is the "Nuevo Rocafuerte" community, part of the Aguarico Canton located in the province of Orellana in the Ecuadorian Amazon, see Figure 1. This community is located at a latitude of $0^{\circ} 56^{\prime} 00$ " South and a length of $75^{\circ}$ $24^{\prime} 00$ " West. The number of inhabitants until the last census conducted in 2010 was 1,024 , according to the National Institute of Statistics and Census (INEC). The economy is mostly based on agriculture and fishing. 
Today, according to the National Electricity Corporation (CNEL) in the area of "Nuevo Rocafuerte" there are electric generators powered by diesel, which operate from 09:00 to 24:00, making it difficult for most of the inhabitants to carry out their activities outside of the established schedule. On the other hand, building electricity transmission lines is environmentally and economically unfeasible, since the community is surrounded by two natural reserves.

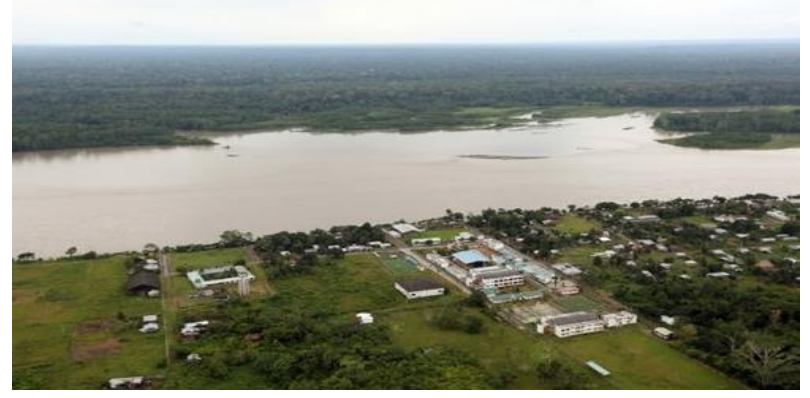

Figure 1

Community "Nuevo Rocafuerte", province of Orellana

Source: (National Institute of Statistics and Census - INEC)

\subsection{Demographic Profile and Meteorological Data of the Studied Community}

The inhabitants of the area cannot enjoy the comforts provided by a power generation system that supplies electricity all day. The annual average solar radiation in the area is $4.35 \mathrm{kWh} / \mathrm{m}^{2} /$ day and the clarity index is 0.43 (NASA Prediction of Worldwide Energy Resources). Figure 2 represents the hourly solar radiation of the selected area using the Homer software database [41].

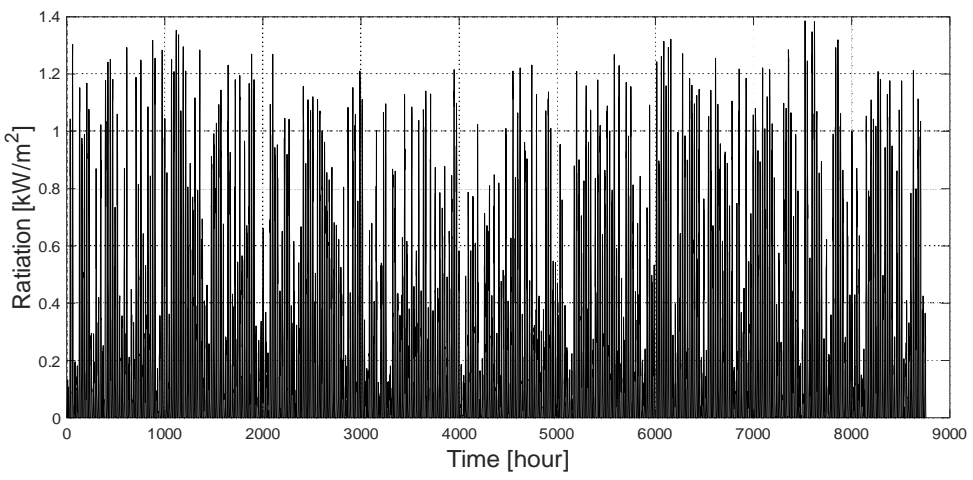

Figure 2

Solar Radiation in the community 
Additionally, the flow $\left(\mathrm{m}^{3} / \mathrm{s}\right)$ and the monthly average speed $(\mathrm{m} / \mathrm{s})$ of the Napo River are shown in Table 1, with a value of $2.34 \mathrm{~m} / \mathrm{s}$.

Figure 3 presents the speed of the river as developed by the HOMER software. It is demonstrated that there is a variation range of $1.8 \mathrm{~m} / \mathrm{s}$ to $4 \mathrm{~m} / \mathrm{s}$ throughout the year, with the months of October, November and December being those with the greatest variations. This information will be considered later in the analysis and optimal sizing of the hydrokinetic turbine.

Table 1

Contains the Flow and speed of the Napo River in "Nuevo Rocafuerte"

\begin{tabular}{|l|l|l|}
\hline Flow $(\mathrm{m} 3 / \mathrm{s})$ & Months & River speed $(\mathrm{m} / \mathrm{s})$ \\
\hline 1500 & Jan & 2.591 \\
\hline 1600 & Feb & 2.656 \\
\hline 1800 & Mar & 2.526 \\
\hline 2100 & Apr & 2.62 \\
\hline 2900 & May & 2.859 \\
\hline 3000 & Jun & 2.81 \\
\hline 2600 & Jul & 2.739 \\
\hline 2200 & Aug & 2.46 \\
\hline 1800 & Sep & 2.591 \\
\hline 1800 & Oct & 2.227 \\
\hline 1800 & Nov & 2.469 \\
\hline 2100 & Dec & 2.54 \\
\hline & &
\end{tabular}

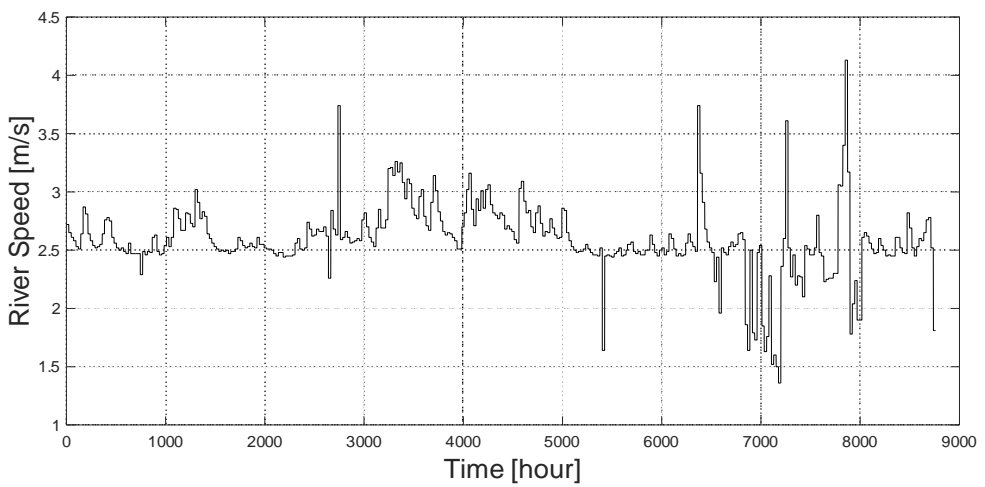

Figure 3

River Speed

\subsection{Estimation of Electricity Consumption Community}

The habits of the inhabitants of the area under study do not vary substantially with respect to the rest of Ecuadorians. According to the Electricity Corporation of 
Ecuador (CELEC EP), the maximum of the national electricity demand occurs between 19:00 to 20:00, and the minimum between 01:00 and 05:00. Since there is no exact data of the demand of the inhabitants of the area, an approximation is made regarding the national demand (See Figure 4).

When it comes to energy consumption, a group of loads is considered typical of a household located in rural areas, it is assumed the use of LED lighting and efficient refrigerators of reduced size. Table 2 indicates the common alternating current loads for the system. It should be mentioned that DC loads are not analyzed, since they are not common, even for this type of applications. The loads presented are estimated according to the customs and climate of the area.

Table 2

Customers Load

\begin{tabular}{|l|l|l|l|l|l|l|}
\hline Description & Quantity & $\begin{array}{l}\text { Current } \\
(\mathrm{A})\end{array}$ & $\begin{array}{l}\text { Power } \\
(\mathrm{W})\end{array}$ & $\begin{array}{l}\text { Hours / } \\
\text { day }\end{array}$ & $\begin{array}{l}\text { Days / } \\
\text { week }\end{array}$ & $\begin{array}{l}\text { Weekly } \\
\text { consumption } \\
\text { (Wh) }\end{array}$ \\
\hline LED light & 3 & 0.1 & 10 & 4 & 7 & 280 \\
\hline TV & 1 & 0.2 & 25 & 6 & 7 & 1,050 \\
\hline Radio & 1 & 0.15 & 20 & 3 & 7 & 420 \\
\hline Cell charger & 1 & 0.05 & 5 & 5 & 3 & 75 \\
\hline Alarm clock & 1 & 0.05 & 5 & 24 & 7 & 840 \\
\hline $\begin{array}{l}\text { Installed } \\
\text { power (W) }\end{array}$ & $\begin{array}{l}\text { Simultaneo } \\
\text { us power }\end{array}$ & $\begin{array}{l}\text { Weekly } \\
\text { energy } \\
(\mathrm{Wh})\end{array}$ & Losses & $\begin{array}{l}\text { Monthly } \\
\text { energy } \\
\text { (Wh) }\end{array}$ & & \\
\hline 65 & 52 & 2,665 & 0.05 & 10,127 & & \\
\hline
\end{tabular}

According to Table 2, the demand in each house is $65 \mathrm{~W}$ on average, since the population of "Nuevo Rocafuerte" is approximately 1,000 inhabitants. Considering the average family consisting of 3 to 4 members including street lighting, the total installed power would be approximately $20 \mathrm{~kW}$. It can be seen that peak demand occurs between 19:00 and 20:00.

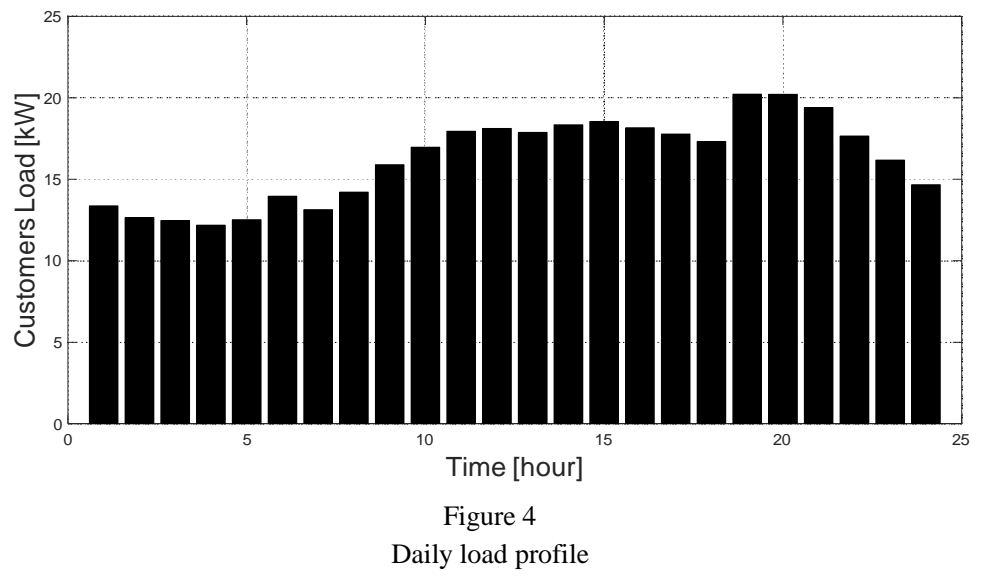


There are no significant variations during the year (Figure 5).

Figure 5 presents the seasonal load profile obtained by [19], based on real data from the area. To model the system, it is very important to use one hour intervals during a year.

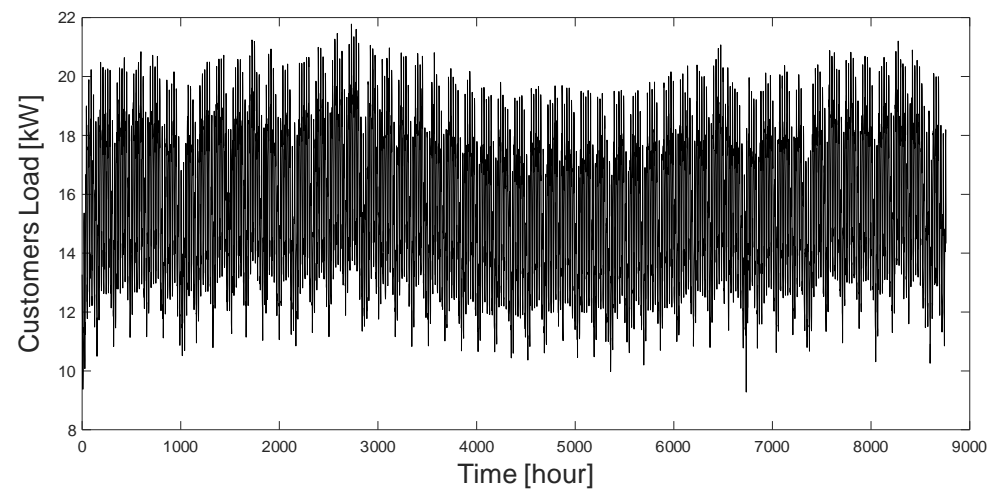

Figure 5

Seasonal load profile

\section{Modeling - Sources of Generation and Storage}

\subsection{Modeling of the Photovoltaic Solar System (PV)}

The performance of a solar module varies according to the climatic conditions of the installation site [42].

The photovoltaic power varies according to the incident solar radiation in the module and the environmental factors (ambient temperature, humidity, etc.). The system power is calculated using equation (1). Where $\mathrm{Y}_{\mathrm{PV}}(\mathrm{kW})$ is the photovoltaic generator nominal capacity, $\mathrm{f}_{\mathrm{PV}}(\%)$ is the reduction factor $\mathrm{I}_{\mathrm{T}}\left(\mathrm{kW} / \mathrm{m}^{2}\right)$ is the solar energy from the incident irradiation in the photovoltaic module, $\mathrm{I}_{\mathrm{S}}\left(\mathrm{kW} / \mathrm{m}^{2}\right)$ is the incident solar radiation under standard test conditions, $\alpha_{\mathrm{P}}$ is the temperature coefficient of the power, $\mathrm{T}_{\mathrm{c}}\left({ }^{\circ} \mathrm{C}\right)$ is the $\mathrm{PV}$ cell temperature, and $\mathrm{T}_{\mathrm{S}}\left({ }^{\circ} \mathrm{C}\right)$ Temperature of the photovoltaic cell under standard test conditions $\left(25^{\circ} \mathrm{C}\right)$ [42].

$$
P_{P V}=Y_{P V} f_{P V} \cdot\left(\frac{I_{T}}{I_{S}}\right) \cdot\left[1+a_{P}\left(T_{c}-T_{S}\right)\right.
$$

The cell temperature is obtained by equation (2). 


$$
T_{c}=T_{a}+I_{T} \frac{T_{c, N O C T}-T_{a, N O C T}}{I_{T, N O C T}}\left(1-\frac{h_{P V}}{t a}\right)
$$

Where:

$\mathrm{T}_{\mathrm{a}}$, Is the ambient temperature, $\tau \alpha$ is the absorption transmittance of the photovoltaic module. In general, HOMER takes it as 0.9, NOCT is the nominal temperature of the operating cell that results in a solar radiation of $800 \mathrm{~W} / \mathrm{m}^{2}$, at an ambient temperature of $20{ }^{\circ} \mathrm{C}$ and in unloaded conditions and $\eta_{\mathrm{PV}}$ is the panel efficiency. In the study area there is an average temperature of approximately 25 ${ }^{\circ} \mathrm{C}$, the best option is to use polycrystalline solar panels [42]. This study uses the parameters of the US commercial solar module SunPower, model E20-327, $360 \mathrm{~W}$ of peak power with an efficiency of $17 \%$, polycrystalline and with a power coefficient of $-0.37 \% /{ }^{\circ} \mathrm{C}$. In this system, the tracking system and the $80 \%$ rating reduction factor have not been taken into account.

The system mode in SDO is shown below:

The function $\mathrm{f}(\mathrm{u})$ is represented by Equation (1)

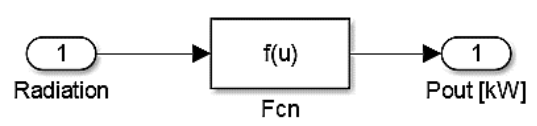

Figure 6

Simulated photovoltaic system in SDO

\subsection{Modeling Hydrokinetic System (HKT)}

In this study, taken into consideration the river speed characteristic, the hydrokinetic turbine has been selected (Smart Hydro Power, Feldang, Germany 5 $\mathrm{kW}$ ). The power of the hydrokinetic turbine is given by equation (3) [25].

$$
P_{H K T}=\frac{1}{2} \cdot r w \cdot A \cdot v^{3} \cdot C_{p, H} \cdot h_{H K T}
$$

The energy is given by:

$$
E_{H K T}=P_{H K T} \cdot t
$$

It is important to consider that the river velocity profile applies to open channel.

In the open channel flow, the velocity of the river at a certain point above the river bed is considered a power function that uses the depth relationship. The average velocity in time $(u)$, the normal distance of the rising bed above the reference $(y)$, the velocity at the point ' $a$ "' where it deviates vertically from the river bottom $\left(u_{a}\right)$ and the exponent of the power law $(1 / m),[4]$. 


$$
\frac{u}{u_{a}}=\left(\frac{y}{y_{a}}\right)^{\frac{1}{m}}
$$

The system mode in SDO is shown below:

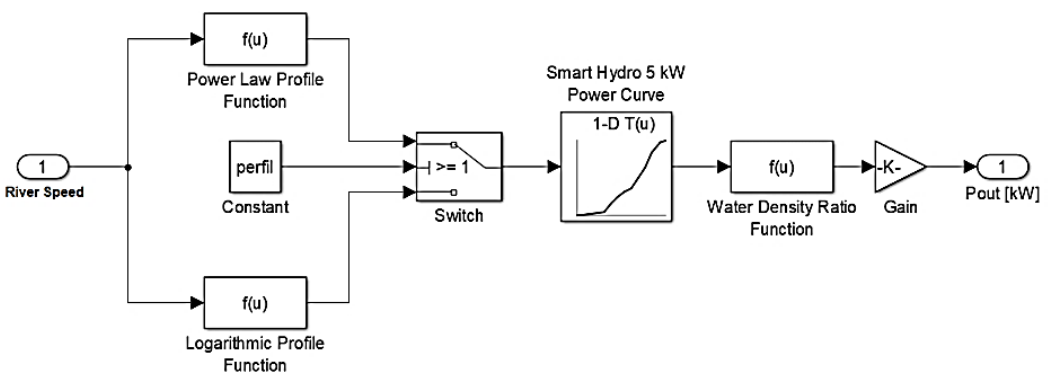

Figure 7

Hydrokinetic turbine in SDO

\subsection{Modeling of the Diesel Generator (DG)}

As mentioned in the previous section, the supply of electrical energy from renewable sources is random depending on the available resource. To ensure the reliability of the supply, it has been decided to use diesel generators as a backup system in case there is no solar radiation in times of low water and if the bank of batteries is discharged. HOMER calculates the capacity of the diesel generator with an additional $10 \%$ to the highest peak of present demand with a life expectancy of $15000 \mathrm{~h}$. The maximum load ratio of the generator is $25 \%$. The fuel consumption for the production of electricity is calculated according to equation (6) [43].

$$
F=F_{0, d g} Y_{d g}+F_{1 d g} P_{d g}
$$

Where, $F_{0}$ is the intercept coefficient of the fuel curve $\left(0.000205 \mathrm{~m}^{3} / \mathrm{h}\right), \mathrm{F}_{1}$ is the slope of the fuel curve $\left(0.00025 \mathrm{~m}^{3} / \mathrm{h} / \mathrm{kW}\right), \mathrm{Y}_{\mathrm{dg}}(\mathrm{kW})$ is the rated capacity of the generator and $\mathrm{P}_{\mathrm{dg}}(\mathrm{kW})$ is the electrical power. The lowest calorific value of diesel fuel is $43.2 \mathrm{MJ} / \mathrm{kg}$ with a density of $820 \mathrm{~kg} / \mathrm{m}^{3}$ [43].

The work factor (DF) $(\mathrm{kWh} / \mathrm{start}$-stop/year) is the power generation ratio of the supplementary primary motors to the total start-stop and can be calculated using equation (7), where $\mathrm{N}_{\mathrm{s} / \mathrm{s}}$ is the number of starts and stops [44].

$$
D F=\frac{P_{d g}}{N_{s / s}}
$$


The energy dispatch of the diesel generator will be carried out depending on the hybrid system conditions. When the generation and demand are disproportionate, a shutdown of the electrical system can be produced since its generation sources would not be able to maintain the load.

The generation, $(\mathrm{PV}+\mathrm{HKT})$ must be equal to the consumption (Load + Pbat). When this equality condition is not met, the diesel generator must be turned on to supply the demand. Also, if the objective function (PV + HKT-Load-Pbat) is in the stability zone, that is, the generation must be greater than or equal to the demand, the generator must be turned off. For the simulation a first-order model is used so that the fuel consumption is a function of the mechanical power and speed of the engine [45].

The system mode in SDO is shown below:

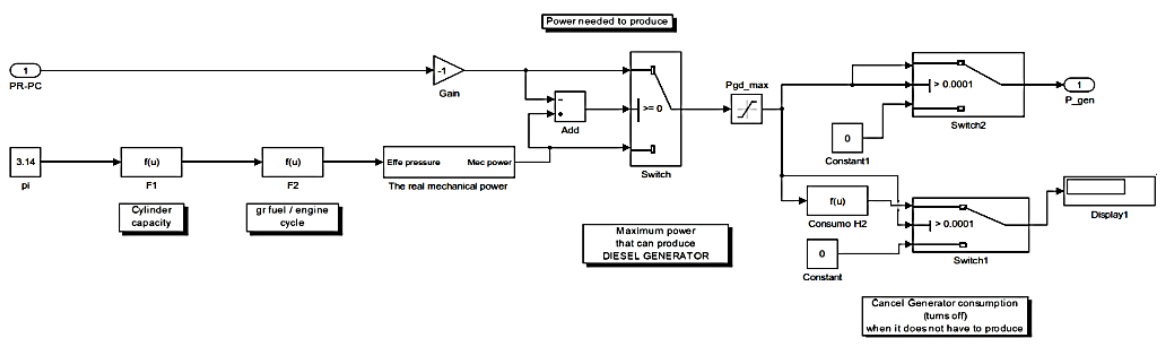

Figure 8

Diesel generator in SDO

\subsection{Modeling of the Storage System (Li-ion)}

In this study, a Lithium Ion battery bank is used as a storage system. The process of charging the batteries begins when the generation of electric power is greater than the consumption. In the same way, when the renewable system is not sufficiently capable of producing energy according to the demand (dry season or low solar radiation), the load will be supply through the storage system. Considering the state of charge (SOC) of the batteries, a charge and discharge limit can be established.

The capacity of a battery is defined as the maximum charge that can be extracted from a battery when it is fully charged. [46], (International Standard IEC 6142761432). According to [19], several equations are used to determine the charge and discharge power of the Lithium Ion battery. Equation (8) determines the maximum load power of the storage system (battery). 


$$
P_{b}(t)=\frac{k Q_{1}(t) e^{-k}+Q(t) k c\left(1-e^{-k D t}\right)}{1-e^{-k D t}+c\left(k D t-1+e^{-k D t}\right)}
$$

Where: $Q_{1}(t)$ refers to the energy available at the beginning of the operating range and above the minimum load state (SOC), in the case of Lithium Ion batteries is $20 \%$, the maximum SOC will be $100 \%$. Q ( $\mathrm{t}$ ) it is the total energy at the beginning of the passage of time, $\mathrm{c}$ is the ratio of the storage capacity of each system, $\mathrm{k}$ is the constant energy storage rate, and $\Delta \mathrm{t}$ is the time interval. The maximum power can be calculated with the following equation:

$$
P_{b}(t)=\frac{k Q_{\text {max }}(t) e^{-k}+k Q_{1}(t) e^{-k}+Q(t) k c\left(1-e^{-k D t}\right)}{1-e^{-k D t}+c\left(k D t-1+e^{-k D t}\right)}
$$

Where $\mathrm{Q}_{\max }(\mathrm{t})$ is the total storage capacity.

Homer calculates the life span of the battery according to its performance. In this case different parameters that help to choose the optimal combination of the system are compared.

In order to determine the number of batteries necessary, factors such as the life span of the hybrid system and that of every battery should be considered [19].

$$
N_{b a t}=\operatorname{ceil} \cdot \frac{\left(V_{S H}{ }^{\cdot V i d a} a_{b t}^{p u, a \tilde{n} o}\right)}{\left(T_{b a t}^{v i d a}\right)}
$$

Where:

$\mathrm{N}_{\text {bat }} \quad$ - batteries number

$\mathrm{T}_{\mathrm{bat}}^{\mathrm{vida}} \quad$ - time period from beginning of the year to the last battery is replaced

Vida $_{\mathrm{SH}} \quad$ - life cycle of the hybrid system (25 years in this case)

$\operatorname{Vida}_{\mathrm{bt}}^{\mathrm{pu}, \mathrm{año}}$ - battery life in the last year

Ceil - sum of the battery bank

The system mode in SDO is shown below: 


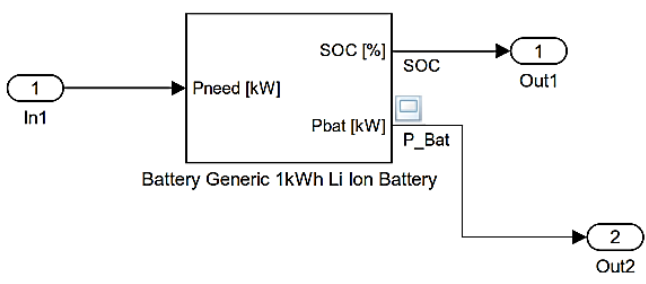

Figure 9

Storage system control in SDO

\section{Energy System Control}

Starting from the objective function (PFV + HKT-Load-Pbat), the power of the $\mathrm{PV}, \mathrm{HKT}$ and the storage system composed of Lithium Ion batteries (Pbat), are defined as adjustment variables. (DG) is set as a fixed variable, given the fact that the continuity of the electricity supply must be ensured under any contingency.

The limit values of each parameter depend on the expressed mathematical model. For example, the battery state of charge will indicate the operating time of the diesel generator according to the load and weather conditions at each instant. Whereas, the work objective is to reduce the diesel generator operation hours without removing the continuity of the electric service, the state of charge of the batteries is defined as an input signal.

In normal climatic conditions, the demand will be satisfied by the (PV/HKT), with fully charged batteries, in times of high demand between 19:00 and 21:00, there will only be HKT generation. If there is a generation deficit, the storage system provides the energy to meet the demand. In case of hydrokinetic power deficit, the battery bank must supply all the available electricity at night time (PV power $=0$ ). When the batteries are discharged at a minimum SOC level (20\%), the diesel generator should start charging the batteries as a priority. The generator must be turned off when the renewable power is greater than the demand and the batteries are charged.

In this study, the option of optimization was selected through Pattern Search in Matlab, since it allows finding appropriate values for the adjustment parameters. In addition, three of the five algorithms available for the search of patterns are considered, in order to ensure that the convergence is correct. It has been selected within the toolbox "Matlab/Simulink Design Optimization", the Genetic Algorithm, Latin Hypercube and the Nelder-Mead, since they obtain values that correspond to those obtained by using HOMER, as indicated in Figure 10. 


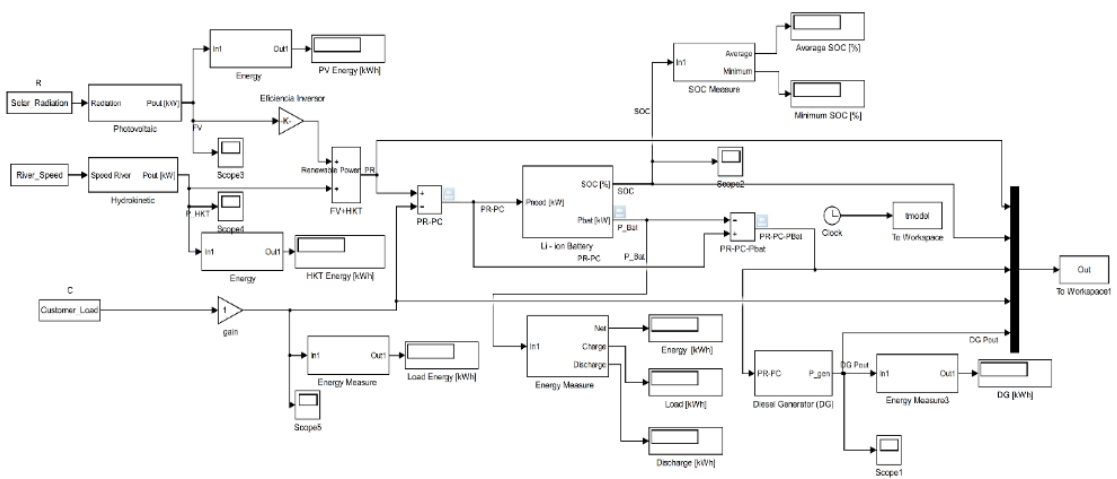

Figure 10

Simulation in Simulink Design Optimization

Figure 11 depicts the simulated Homer system, where both the batteries and the photovoltaic system are connected to a direct current bus. The (HKT, DG and Customers load) are connected to the alternating current bus. The energy is taken from the $\mathrm{PV} / \mathrm{Li}$-ion system to the load though an inverter, and the excess energy is stored in the batteries by means of a rectifier (Converter).

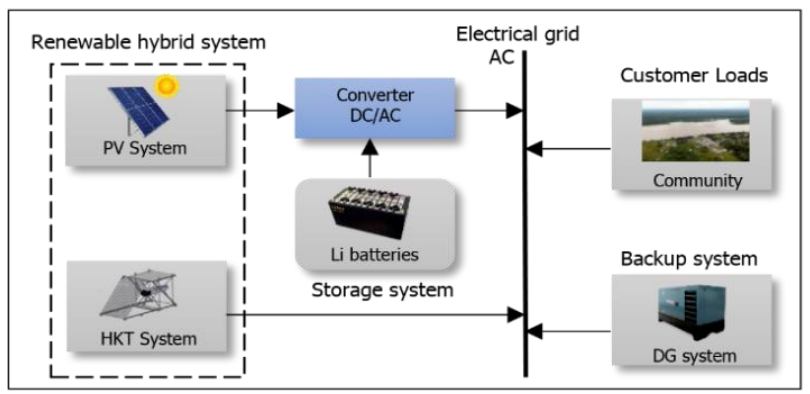

Figure 11

Schematic of the Hybrid System

\section{Results and Comments}

Figure 12 shows the operating logic for the proposed system. It is evident that, this type of control allows the diesel generator to start only if the batteries need to be recharged and not directly to feed the electrical demand, as explained in Section 4. This insures a reduction of the DG operational hours. In Fig. 8, this type of system behavior is observed. If the Customers Load $(\mathrm{kW})$ is greater than Renewable Pout $(\mathrm{kW})$ and when the State Of Charge (\%) is less than SOCmin (20\%), the diesel generator starts at full load recharging the batteries, until the Li-ion have been 
charged at least $80 \%$ in such a way as to supply the load, at that point the diesel generator turns off.

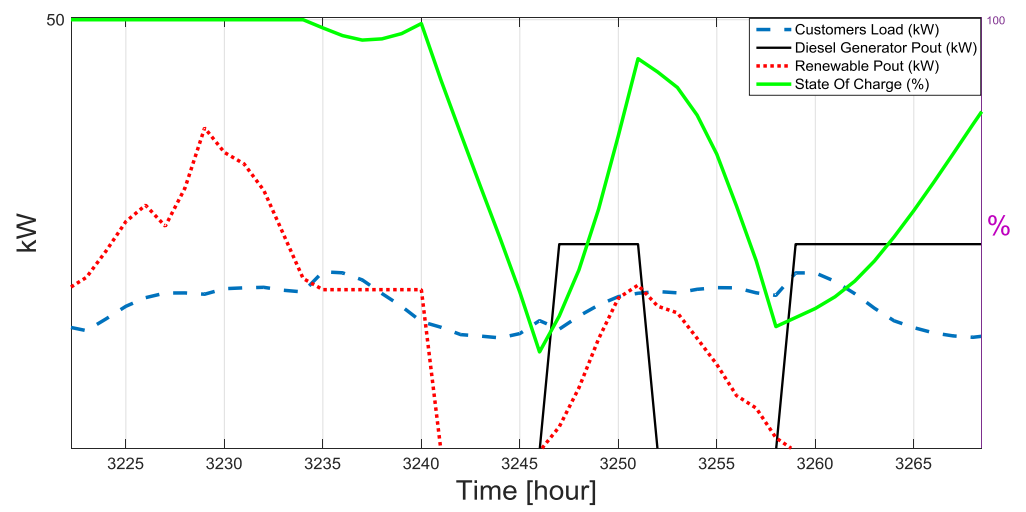

Figure 12

System operation

The results of the energy production necessary to supply the annual demand are shown in Figure 13. These results have been obtained through HOMER.

The largest contribution corresponds to the hydrokinetic generation system, with $78.87 \%$. The photovoltaic generation represents $19.59 \%$ of the total energy production and finally the contribution of the diesel generator is merely $1.53 \%$.

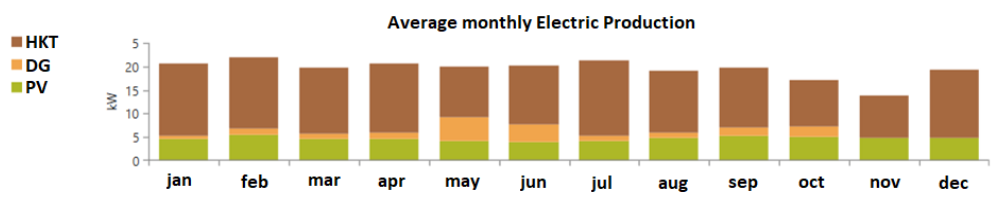

Figure 13

Electric Production

Figure 14 shows SOC of the storage system, during a year. Since October, the flow rate of river Napo is low and its velocity decreases. In this way, the batteries have to supply the load at night, since the photovoltaic system is not in operation. Here, there is an optimal system response. The generator does not allow the state of charge of the batteries to fall below 20\%, thus increasing the life span of the storage system. By comparison, during the months of June and July there are enough water and solar resources to supply the demand. Figure 14 shows that in these months the batteries' SOC remains at a value close to $100 \%$, apart from some discharge peaks that can be attributed to the known random behavior of renewable sources. 


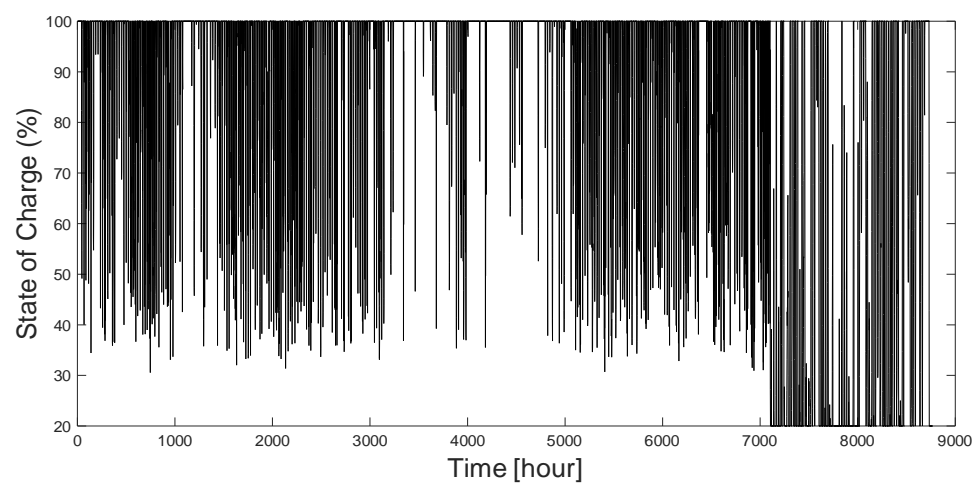

Figure 14

Li-ion batteries SOC

Conversely, the results using SDO algorithms, with respect to, Homer, are similar. Nevertheless, the contribution of the diesel generator is lower according to SDO algorithms, due to the fact that in this software, the generator is intended to operate as little as possible without taking into account extra costs in replacement of the storage system (as HOMER does).

In Tables 3 and 4 the results of the optimization of the power can be compared with Matlab and HOMER.

Table 3

Sizing and operation of the diesel generator

\begin{tabular}{|l|l|l|l|l|l|}
\hline Algorithm & $\begin{array}{l}\mathrm{PV} \\
(\mathrm{kW})\end{array}$ & $\begin{array}{l}\text { HKT } \\
(\mathrm{kW})\end{array}$ & $\begin{array}{l}\text { DG } \\
(\mathrm{kW})\end{array}$ & $\begin{array}{l}\text { Li-ion } \\
(\mathrm{kWh})\end{array}$ & $\begin{array}{l}\text { Switch on } \\
\text { DG/yr }\end{array}$ \\
\hline $\begin{array}{l}\text { Latin } \\
\text { Hypercube }\end{array}$ & 32.03 & 21.04 & 25 & 518.95 & 124 \\
\hline $\begin{array}{l}\text { Genetic } \\
\text { algorithm }\end{array}$ & 31.05 & 20.56 & 25 & 513.54 & 155 \\
\hline Nelder-mead & 30 & 20 & 25 & 530 & 118 \\
\hline Homer & 30 & 20 & 24 & 100 & 237 \\
\hline
\end{tabular}

Table 4

Annual energy produced by each component

\begin{tabular}{|l|r|r|r|l|}
\hline Algorithm & \multicolumn{1}{|l|}{$\begin{array}{l}\text { PV } \\
(\mathrm{kWh} / \mathrm{yr})\end{array}$} & $\begin{array}{l}\mathrm{HKT} \\
(\mathrm{kWh} / \mathrm{yr})\end{array}$ & $\begin{array}{l}\text { DG } \\
(\mathrm{kWh} / \mathrm{yr})\end{array}$ & $\begin{array}{l}\text { Li-ion } \\
(\mathrm{kWh} / \mathrm{yr})\end{array}$ \\
\hline Latin Hypercube & 43,952 & 114,758 & 15,856 & $37,840.15$ \\
\hline $\begin{array}{l}\text { Genetic } \\
\text { algorithm }\end{array}$ & 43,887 & 114,568 & 14,589 & 32,945 \\
\hline Nelder-mead & 43,576 & 114,327 & 11,968 & 48,280 \\
\hline Homer & 41,101 & 115,080 & 17,228 & $3,023.9$ \\
\hline
\end{tabular}


In Table 3, the Nelder-mead algorithm calculates 118 diesel generator starts, genetic algorithm 118 starts, 124 for Latin hyper-cube and 237 for homer. However, the largest storage capacity is calculated by Nelder-mead (530 kWh). The generation sources power is similar between SDO and Homer, however, Homer calculates the lowest capacity of all the components of the system.

The energy contribution of the diesel generator is lower in Nelder-mead and the highest in the Homer result. Yet, the highest battery system result is attributed to the Nelder-mead, whereas the lowest to Homer, maintaining similar values in terms of generation by PV/HKT.

The similarity of the size of the system shown by the two simulations is evident. It is obvious that since there is a high water resource, the penetration of hydrokinetic energy is greater than the photovoltaic. The novelty is that SDO considers it viable to increase the storage system reducing the DG operation, unlike Homer, which considers it a better option to use the diesel generator more times with lower power in each one, reducing the capacity of the batteries, creating an economic optimization.

\section{Conclusions}

The results show that the hybrid system is able to supply the demand of the community throughout an entire year, since the meteorological conditions of Nuevo Rocafuerte are adequate for this purpose. With the obtained results, the use of alternative energies in Ecuador can be enhanced. In addition, there are numerous protected areas of the Amazon where rural populations are located.

The result of the research shows that it is possible to include a hybrid renewable energies system in the area, apart from the existing one that consists solely of diesel generators. One of the most important aspects shows that continuity of an electricity supply for the community is not compromised. Furthermore, his reduction of transport expenses and diesel consumption is evident, even without carrying out a cost analysis, not to mention, reducing emissions of greenhouse gases produced by DG.

The analysis carried out by Simulink Design Optimization does not take into account the minimization of system costs, since it is focused on reducing the operation of the diesel generator ensuring the continuity of the electric generation by optimizing the photovoltaic and hydrokinetic design. The variability of renewable energy sources could hinder the normal operation of hybrid system, therefore, it is recommended to perform a stability study of this system. Finally, another important aspect, is to consider is the use of Lithium Ion batteries, because in the near future, they will be used more frequently than lead based batteries. Future work will consider the use of storage systems composed of different technologies, with the aim of studying the effects they would produce within the proposed hybrid system. 


\section{References}

[1] M. Ten Palomares and A. Boni Aristizabal, "Visiones de la electrificación rural en la Amazonía Ecuatoriana: disputando lógicas hegemónicas," Let. Verdes. Rev. Latinoam. Estud. Socioambientales, No. 20, p. 4, Oct. 2016

[2] R. Luna-Rubio, M. Trejo-Perea, D. Vargas-Vázquez, and G. J. RíosMoreno, "Optimal sizing of renewable hybrids energy systems: A review of methodologies,” Sol. Energy, Vol. 86, No. 4, pp. 1077-1088, Apr. 2012

[3] H. J. Vermaak, K. Kusakana, and S. P. Koko, "Status of micro-hydrokinetic river technology in rural applications: A review of literature," Renewable and Sustainable Energy Reviews, Vol. 29, pp. 625-633, Jan-2014

[4] J. Lata-García, F. Jurado, L. M. Fernández-Ramírez, and H. Sánchez-Sainz, "Optimal hydrokinetic turbine location and techno-economic analysis of a hybrid system based on photovoltaic/hydrokinetic/hydrogen/battery," Energy, Vol. 159, pp. 611-620, Sep. 2018

[5] R. J. Cevallos Meza and M. E. Ruales Lara, "Estudio de la geodinámica actual del río Napo (Amazonía Ecuatoriana - Peruana) usando datos hidrológicos y de DGPS," 2005

[6] B. K. Das, Y. M. Al-Abdeli, and M. Woolridge, "Effects of battery technology and load scalability on stand-alone PV/ICE hybrid micro-grid system performance," Energy, Vol. 168, pp. 57-69, Feb. 2019

[7] C. Ammari, M. Hamouda, and S. Makhloufi, "Comparison Between Three Hybrid System PV/Wind Turbine/Diesel Generator/Battery Using HOMER PRO Software,” 2019, pp. 227-237

[8] S. Ahmadi and S. Abdi, "Application of the Hybrid Big Bang-Big Crunch algorithm for optimal sizing of a stand-alone hybrid PV/wind/battery system," Sol. Energy, Vol. 134, pp. 366-374, Sep. 2016

[9] A. Cano, F. Jurado, H. Sánchez, L. M. Fernández, and M. Castañeda, "Optimal sizing of stand-alone hybrid systems based on PV/WT/FC by using several methodologies," J. Energy Inst., Vol. 87, No. 4, pp. 330-340, Nov. 2014

[10] R. Dufo-López et al., "Multi-objective optimization minimizing cost and life cycle emissions of stand-alone PV-wind-diesel systems with batteries storage," Appl. Energy, Vol. 88, No. 11, pp. 4033-4041, Nov. 2011

[11] M. Jamshidi and A. Askarzadeh, "Techno-economic analysis and size optimization of an off-grid hybrid photovoltaic, fuel cell and diesel generator system," Sustain. Cities Soc., Vol. 44, pp. 310-320, Jan. 2019

[12] M. Castañeda, A. Cano, F. Jurado, H. Sánchez, and L. M. Fernández, "Sizing optimization, dynamic modeling and energy management strategies of a stand-alone PV/hydrogen/battery-based hybrid system," Int. J. Hydrogen Energy, Vol. 38, No. 10, pp. 3830-3845, Apr. 2013 
[13] D. N. Luta and A. K. Raji, "Optimal sizing of hybrid fuel cellsupercapacitor storage system for off-grid renewable applications," Energy, Vol. 166, pp. 530-540, Jan. 2019

[14] F. K. Abo-Elyousr and A. Elnozahy, "Bi-objective economic feasibility of hybrid micro-grid systems with multiple fuel options for islanded areas in Egypt," Renew. Energy, Vol. 128, pp. 37-56, Dec. 2018

[15] O. Djelailia, M. S. Kelaiaia, H. Labar, S. Necaibia, and F. Merad, "Energy hybridization photovoltaic/diesel generator/pump storage hydroelectric management based on online optimal fuel consumption per kWh," Sustain. Cities Soc., Vol. 44, pp. 1-15, Jan. 2019

[16] M. Belouda, M. Hajjaji, H. Sliti, and A. Mami, "Bi-objective optimization of a standalone hybrid PV-Wind-battery system generation in a remote area in Tunisia," Sustain. Energy, Grids Networks, Vol. 16, pp. 315-326, Dec. 2018

[17] R. Sarrias-Mena, L. M. Fernández-Ramírez, C. A. García-Vázquez, and F. Jurado, "Fuzzy logic based power management strategy of a multi-MW doubly-fed induction generator wind turbine with battery and ultracapacitor," Energy, Vol. 70, pp. 561-576, Jun. 2014

[18] R. Sarrias-Mena, L. M. Fernández-Ramírez, C. A. García-Vázquez, and F. Jurado, "Improving grid integration of wind turbines by using secondary batteries," Renew. Sustain. Energy Rev., Vol. 34, pp. 194-207, Jun. 2014

[19] J. P. Torreglosa, P. García-Triviño, L. M. Fernández-Ramirez, and F. Jurado, "Control based on techno-economic optimization of renewable hybrid energy system for stand-alone applications," Expert Syst. Appl., Vol. 51, pp. 59-75, Jun. 2016

[20] J. P. Torreglosa, P. García, L. M. Fernández, and F. Jurado, "Energy dispatching based on predictive controller of an off-grid wind turbine/photovoltaic/hydrogen/battery hybrid system," Renew. Energy, Vol. 74, pp. 326-336, Feb. 2015

[21] W. Zhang, A. Maleki, M. A. Rosen, and J. Liu, "Optimization with a simulated annealing algorithm of a hybrid system for renewable energy including battery and hydrogen storage," Energy, Vol. 163, pp. 191-207, Nov. 2018

[22] W. Zhang, A. Maleki, M. A. Rosen, and J. Liu, "Sizing a stand-alone solarwind-hydrogen energy system using weather forecasting and a hybrid search optimization algorithm," Energy Convers. Manag., Vol. 180, pp. 609-621, Jan. 2019

[23] S. C. Bhattacharyya, "Energy access programmes and sustainable development: A critical review and analysis," Energy Sustain. Dev., Vol. 16, No. 3, pp. 260-271, Sep. 2012

[24] B. K. Das and F. Zaman, "Performance analysis of a PV/Diesel hybrid 
system for a remote area in Bangladesh: Effects of dispatch strategies, batteries, and generator selection," Energy, Vol. 169, pp. 263-276, Feb. 2019

[25] J. Lata-Garcia, F. Jurado-Melguizo, H. Sanchez-Sainz, C. Reyes-Lopez, and L. Fernandez-Ramirez, "Optimal sizing hydrokinetic-photovoltaic system for electricity generation in a protected wildlife area of Ecuador," Turkish J. Electr. Eng. Comput. Sci., Vol. 26, No. 2, pp. 1103-1114, 2018

[26] P. García, J. P. Torreglosa, L. M. Fernández, and F. Jurado, “Optimal energy management system for stand-alone wind turbine/photovoltaic/ hydrogen/battery hybrid system with supervisory control based on fuzzy logic," Int. J. Hydrogen Energy, Vol. 38, No. 33, pp. 14146-14158, Nov. 2013

[27] A. Abdelkader, A. Rabeh, D. Mohamed Ali, and J. Mohamed, "Multiobjective genetic algorithm based sizing optimization of a stand-alone wind/PV power supply system with enhanced battery/supercapacitor hybrid energy storage," Energy, Vol. 163, pp. 351-363, Nov. 2018

[28] A. Farmann, W. Waag, A. Marongiu, and D. U. Sauer, "Critical review of on-board capacity estimation techniques for lithium-ion batteries in electric and hybrid electric vehicles," J. Power Sources, Vol. 281, pp. 114-130, May 2015

[29] C. D. Rodríguez-Gallegos, O. Gandhi, M. Bieri, T. Reindl, and S. K. Panda, "A diesel replacement strategy for off-grid systems based on progressive introduction of PV and batteries: An Indonesian case study," Appl. Energy, Vol. 229, pp. 1218-1232, Nov. 2018

[30] K. S. El-Bidairi, H. Duc Nguyen, S. D. G. Jayasinghe, T. S. Mahmoud, and I. Penesis, "A hybrid energy management and battery size optimization for standalone microgrids: A case study for Flinders Island, Australia," Energy Convers. Manag., Vol. 175, pp. 192-212, Nov. 2018

[31] M. Vasquez C., F., F, L., Espinoza, J., \& Garcia R., “(12) (PDF) Energia solar en el Ecuador," 2015

[32] J. Vaščák, "Adaptation of fuzzy cognitive maps by migration algorithms," Kybernetes, Vol. 41, No. 3/4, pp. 429-443, Apr. 2012

[33] R.-E. Precup, M.-B. Rădac, M. L. Tomescu, E. M. Petriu, and S. Preitl, "Stable and convergent iterative feedback tuning of fuzzy controllers for discrete-time SISO systems," Expert Syst. Appl., Vol. 40, No. 1, pp. 188199, Jan. 2013

[34] M. Impr. Bourg-offset), E. Rashedi, S. M. Dashti, and A. Hakimi, Communication, BEP terminale professionnelle: corrigé., Vol. 15, No. 2, Fontaine Picard, 1997

[35] R.-E. Precup, R.-C. David, R.-E. Precup, and R.-C. David, "Introduction," Nature-inspired Optim. Algorithms Fuzzy Control. Servo Syst., pp. 1-54, Jan. 2019 
[36] R.-E. Precup, R.-C. David, R.-E. Precup, and R.-C. David, "Nature-inspired algorithms for the optimal tuning of fuzzy controllers," Nature-inspired Optim. Algorithms Fuzzy Control. Servo Syst., pp. 55-80, Jan. 2019

[37] R.-E. Precup, R.-C. David, R.-E. Precup, and R.-C. David, "Adaptive nature-inspired algorithms for the optimal tuning of fuzzy controllers," Nature-inspired Optim. Algorithms Fuzzy Control. Servo Syst., pp. 81-101, Jan. 2019

[38] R.-E. Precup, R.-C. David, R.-E. Precup, and R.-C. David, "Hybrid natureinspired algorithms for the optimal tuning of fuzzy controllers," Natureinspired Optim. Algorithms Fuzzy Control. Servo Syst., pp. 103-114, Jan. 2019

[39] M. Castaneda, L. M. Fernandez, H. Sanchez, A. Cano, and F. Jurado, "Sizing methods for stand-alone hybrid systems based on renewable energies and hydrogen," in $201216^{\text {th }}$ IEEE Mediterranean Electrotechnical Conference, 2012, pp. 832-835

[40] J. Lata-Garcia, C. Reyes-Lopez, F. Jurado, L. M. Fernandez-Ramirez, and H. Sanchez, "Sizing optimization of a small hydro/photovoltaic hybrid system for electricity generation in Santay Island, Ecuador by two methods," in 2017 CHILEAN Conference on Electrical, Electronics Engineering, Information and Communication Technologies (CHILECON), 2017, pp. 1-6

[41] J. W. White, G. Hoogenboom, P. W. Stackhouse, and J. M. Hoell, "Evaluation of NASA satellite- and assimilation model-derived long-term daily temperature data over the continental US," Agric. For. Meteorol., Vol. 148, No. 10, pp. 1574-1584, Sep. 2008

[42] S. Mandal, B. K. Das, and N. Hoque, "Optimum sizing of a stand-alone hybrid energy system for rural electrification in Bangladesh," J. Clean. Prod., Vol. 200, pp. 12-27, Nov. 2018

[43] F. Khalid, I. Dincer, and M. A. Rosen, "Thermoeconomic analysis of a solar-biomass integrated multigeneration system for a community," Appl. Therm. Eng., Vol. 120, pp. 645-653, Jun. 2017

[44] A. Askarzadeh, "Distribution generation by photovoltaic and diesel generator systems: Energy management and size optimization by a new approach for a stand-alone application," Energy, Vol. 122, pp. 542-551, Mar. 2017

[45] S. Roy, O. P. Malik, and G. S. Hope, "Adaptive control of speed and equivalence ratio dynamics of a diesel driven power-plant," IEEE Trans. Energy Convers., Vol. 8, No. 1, pp. 13-19, Mar. 1993

[46] M. Mehrabankhomartash, M. Rayati, A. Sheikhi, and A. M. Ranjbar, "Practical battery size optimization of a PV system by considering individual customer damage function," Renew. Sustain. Energy Rev., Vol. 67, pp. 36-50, Jan. 2017 